\title{
NEUROHORMONAL AND PHARMACOLOGICAL REGULATION OF OESTROGEN, PROGESTERONE, LUTEINIZING HORMONE AND FOLLICLE STIMULATING HORMONE OVER THE MENSTRUAL CYCLE - THE POSSIBLE RELEVANCE OF ANGIONTENSIN II
}

\author{
ROXANA MIHAELA BARBU ${ }^{1}$, ALIN CIOBÎCĂ ${ }^{2,3,4}$, BOGDAN AURELIAN STANA ${ }^{1}$, IONUT, \\ RĂDUCU POPESCU ${ }^{1 *}$, WALTHER BILD ${ }^{1,2}$
}

\author{
I "Gr. T. Popa" University of Medicine and Pharmacy, Faculty of Medicine, Physiology Department, Iași, Romania \\ ${ }^{2}$ Center of Biomedical Research of the Romanian Academy, Iași, Romania \\ ${ }^{3}$ Department of Research, Faculty of Biology, "Alexandru Ioan Cuza” University of Iași, 20A Carol I Avenue, Iași, Romania \\ ${ }^{4}$ Academy of Romanian Scientists, 54 Splaiul Independenței, sector 5, 050094, București, România
}

*corresponding author: ionut-raducu.popescu@umfiasi.ro

\begin{abstract}
The menstrual cycle is a series of physiological changes that occur under hormonal control in females during the childbearing age. Its neurohormonal regulation is made via the hypothalamic-pituitary-ovarian axis that regulates hormones levels like luteinizing hormone ( $\mathrm{LH})$ and follicle-stimulating hormone (FSH) and indirectly via oestrogens and progesterone. Their plasma levels can vary during the phases of the menstrual cycle: the follicular, ovulatory and luteal phase. Changes in hormonal balance, in the luteinizing hormone and follicle-stimulating hormone alter the oestrogen/progesterone balance, and can disrupt the menstrual cycle. The aim of this study was to explore the reciprocal relationships between sex steroid hormones, oestrogen and progesterone and gonadotropic hormones, such as luteinizing hormone and follicle-stimulating hormone, during the physiological ovulatory menstrual cycle. For this study we used 20 nulliparous female mice and 15 multiparous female mice. The obtained results show that plasma concentrations of luteinizing hormone, follicle-stimulating hormone and oestrogens were altered significantly between the phases of the menstrual cycle in nulliparous compared to multiparous female mice, but the progesterone values were not different for the two groups of mice studied. It is recognized that ovarian factors, including steroid and protein hormones, are critical in regulating pituitary gonadotropin feedback, but nevertheless, their individual contributions are less defined. We have shown that the administration of angiotensin II, in the same nulliparous and multiparous female mice, in which the hormonal assessment was performed, significantly increases the muscular contractility stimulated by the electric field.
\end{abstract}

\section{Rezumat}

Ciclul menstrual este reprezentat de o serie de modificări fiziologice care se produc sub control hormonal la sexul feminin în timpul vârstei fertile. Reglarea neurohormonală este reprezentată de axa hipotalamo-hipofizo-ovariană care reglează ciclul menstrual. Nivelele de hormoni, precum estrogenul, progesteronul, hormonul luteinizant (LH) și hormonul foliculostimulant (FSH), pot varia în timpul fazelor ciclului menstrual: faza foliculară, ovulatorie și luteală. Modificările echilibrului hormonal, hormonul luteinizant și hormonul foliculostimulant, ale balanței estrogeni/progesteron pot perturba ciclul menstrual. Scopul acestui studiu a fost explorarea relațiilor reciproce dintre hormonii steroizi sexuali, estrogeni și progesteron și hormonii gonadotropi, precum hormonul luteinizant și hormonul foliculostimulant, de-a lungul ciclului ovulator fiziologic. Pentru acest studiu am folosit 20 șoareci femele nulipare și 15 șoareci femele multipare, de la care sângele a fost colectat și ulterior analizat în laborator. Rezultatele obținute arată că hormonul luteinizant, hormonul foliculostimulant și estrogenii s-au schimbat semnificativ între fazele ciclului menstrual la nulipare comparativ cu şoarecii femele multipare, dar valorile progesteronului nu au fost modificate pentru cele două grupuri de șoareci studiați. Se recunoaște că factorii ovarieni, inclusiv hormonii steroizi și proteici, sunt critici în reglarea feedback-ului gonadotropinei hipofizare, dar cu toate acestea, contribuțiile lor individuale sunt mai puțin definite. Am arătat și că administrarea de angiotensină II, la aceiași șoareci femele, nulipare și multipare, la care s-a făcut dozarea hormonală, crește semnificativ contractilitatea musculară stimulată în câmpul electric.

Keywords: menstrual cycle, hormonal dosage, angiotensin

\section{Introduction}

Although it is known that the physiology and pathophysiology of the menstrual cycle has attracted the interest of scientific research since ancient times, for many investigators, the menstrual cycle shows the influence of ovarian steroids on emotion, cognition and human behaviour [35]. In recent years, there have been methodological improvements in menstrual cycle studies in both human and experimental animals [3]. Studies on this topic suggest improved performance 
when we have high levels of oestradiol during the menstrual cycle. Studies of the menstrual cycle on emotional processing, on the other hand, demonstrate the emotional disorders of the luteal phase and may be relevant for women with premenstrual disorders $[7,26]$.

Among the primary female sex hormones, we studied oestrogen and progesterone. Oestrogen and progesterone are hormones secreted by the ovaries, following the influence of the pituitary gland that has an essential role in the regular development of the menstrual cycle. Any imbalance between oestrogen and progesterone will disrupt the development of menstrual cycles and thus cause, among other, delayed menstruation [27]. The oestrogen secretion begins at puberty. As women get older, oestrogen levels decrease as we get closer to menopause [17].

Another female primary sex hormone, progesterone, is a hormone produced by the yellow body of the follicle in the second half of the menstrual cycle and plays a crucial role in the transformation and preparation of the mucosa and the implantation of the fertilized egg. The uterus is the most important target organ of progesterone, which transforms the uterine lining into a tissue rich in glands, and will promote intrauterine implantation of the fertilized egg. During pregnancy, progesterone inhibits the contractions of the myometrium, but also decreases the sensitivity to physiological stimuli of contraction [4]. In the mammary glands, progesterone together with oestradiol stimulates the proliferation and secretory arrangement of the pulmonary alveoli $[9,10]$.

Although studies in mice and rats suggest that progesterone reduces the frequency of the GnRH (gonadotropin-releasing hormone) pulse in 2 to 6 hours [20], the corresponding human data are mixed: some studies suggest rapid slowing (within 8 - $14 \mathrm{~h}$ ) [11], while others suggest that longer progesterone exposure is needed [28]. Among the pituitary hormones, the follicle stimulation hormone (FSH) and luteinizing hormone (LH) are studied. These are secreted by of the pituitary gland which stimulate the appearance of follicles on the surface of the ovaries, induce oestrogen and progesterone production and contribute to the maturation of the egg. The hormones FSH and LH act on the hypothalamus in such way that high doses of FSH inhibit and low doses stimulate the elimination of GnRH. Low-doses of oestradiol stimulates the synthesis and release of FSH and inhibits LH, while high concentrations of oestrogen inhibit FSH and stimulate the release of $\mathrm{LH}$ [23].

Oestrogens induce hepatic angiotensinogen development, which leads to secondary increases in angiotensin and, as a result, aldosterone, thus we can say that the reninangiotensin system is one of the most important general and local hormonal systems in the body, known for the successful regulation of blood pressure and fluid homeostasis. Angiotensin II regulates blood pressure by directly modulating sodium and water reabsorption by stimulating AT-1 receptors in the kidneys or indirectly by stimulating aldosterone production and release from the adrenal glands or by stimulating thirst in the central nervous system [8, 14, 21, 25].

In this context, the purpose of the study was to compare the values of hormonal levels for oestrogen, progesterone, LH and FSH in nulliparous and multiparous female mice, depending on the phase of the menstrual cycle, at the time of blood collection. Another purpose was to observe the effect of angiotensin directly on the uterine smooth muscle, which might also be depending on the contractile alterations induced by the oestrogen/ progesterone balance. In what concerns the exact moment of the oestrous cycle in the female mice, it is known that it is divided into 4 stages (proestrus, oestrus, metestrus and diestrus) and repeats every 4 to 5 days [5] and their succession is best assessed with vaginal cytology [6]. However practical concerns connected to the shortness of this cycle impeded the evaluation of the exact moment in the oestrous cycle of the mice. However, as the mice were housed together during several weeks, it is to be expected that their oestrous cycles were synchronized following a long cohabitation [13].

\section{Materials and Methods}

\section{Experimental animals}

Swiss mice, adult females, of which 20 nulliparous and 15 multiparous weighing 18 - $20 \mathrm{~g}$, were used for all experiments. The animals were housed in individual cages at a temperature of $21 \pm 2^{\circ} \mathrm{C}$, nictemeral cycle of 12 - 12 hours, with food and water ad libitum. All animals were kept in similar environmental and feeding conditions. Euthanasia was performed by anaesthesia with inhaled isoflurane. In the morning, between 8 and 9 am, female Swiss mice were weighed, anesthetized with inhaled isoflurane, and blood samples were collected by taking blood from the left ventricle directly into the vacutainer, approximately $1.5-2 \mathrm{~mL} / \mathrm{mouse}$, then placed immediately on ice. The serum was isolated by centrifugation at 2500x $\mathrm{g}$ for $15 \mathrm{~min}$. The serum was aliquoted and frozen at $-20^{\circ} \mathrm{C}$ until analysis.

Beginning from the fact that oestrogens induce an increase in hepatic angiotensinogen synthesis [16], leading to secondary increases in angiotensin, we continued the series of experiments, so that immediately after taking blood samples and transporting them to the laboratory for hormonal analysis of oestrogen, progesterone, $\mathrm{LH}$ and FSH, by dissection and sectioning, we took uterine fragments in rings of $3-4 \mathrm{~mm}$ which were placed in physiological saline solution (SSF) Krebs - Henseleit type, at $4^{\circ} \mathrm{C}$, with the following composition (mM): $\mathrm{NaCl} 119 ; \mathrm{KCl} 4.7 ; \mathrm{CaCl}_{2} 2.5$; $\mathrm{MgSO}_{4} 1.2 ; \mathrm{NaHCO}_{3} 25 ; \mathrm{KH}_{2} \mathrm{PO}_{4}$ 1.18; glucose 5.5. In the organ bath, the preparations were permanently maintained in bubbled SSF with a mixture of $95 \% \mathrm{O}_{2}$ 
FARMACIA, 2021, Vol. 69, 1

and $5 \% \mathrm{CO}_{2}$, at $37^{\circ} \mathrm{C}$, with a $\mathrm{pH}$ of 7.2 - 7.4. All bioactive substances used were in the research category and were administered directly in the organ bath (useful volume $5 \mathrm{~mL}$ ) in the form of small volumes of stock solutions: $50 \mu \mathrm{L}$; dilution 1:100. The next intervention (washing or other administration) was performed only after the degree of contraction showed a plateau for a period of $5 \mathrm{~min}$. In some cases, the concentration of the bioactive substance tested was gradually increased by the successive administration of identical volumes $(50 \mu \mathrm{L})$ of stock solution with increased concentrations of an order of magnitude (x10) but not more than $250 \mu \mathrm{L}$ in total. Washing was performed by aspirating the pre-existing volume of SSF from the bath, followed by the addition of a similar volume of fresh SSF.

\section{Biochemical assessments}

Oestrogen dosage in female Swiss mice was performed by the competitive ELISA method, using immobilized antigens. Oestradiol is one of the main components of natural oestrogens and is the main oestrogen secreted during the menstrual cycle. The oestradiol calibration range is between $2.5-1280 \mathrm{pg} / \mathrm{mL}$, and the limit of detection of oestradiol in the body is $2.5 \mathrm{pg} / \mathrm{mL}$.

Progesterone was assessed in female Swiss mice using the sandwich ELISA method, using the HRPlabelled antibody. Progesterone is a female steroid hormone with a variety of physiological effects. In the follicular phase of the menstrual cycle, progesterone is produced at low levels. The progesterone calibration range is between $0.4 \mathrm{pg} / \mathrm{mL}-100 \mathrm{pg} / \mathrm{mL}$, and the limit of detection of progesterone is equal to $0.04 \mathrm{pg} / \mathrm{mL}$. The determination of $\mathrm{LH}$ in female Swiss mice was performed by the sandwich ELISA method, using biotin-labelled antibody. Luteinizing hormone (LH) is produced in both men and women in the anterior pituitary gland in response to luteinizing hormonereleasing hormone (LH-RH or Gn-RH), which is released by the hypothalamus. The calibration range of $\mathrm{LH}$ is between $0.313-10 \mathrm{pg} / \mathrm{mL}$, and the limit of detection of LH in the body is equal to $10 \mathrm{pg} / \mathrm{mL}$.

FSH measurement in female Swiss mice was performed by the sandwich ELISA method, using biotin-labelled antibody. The follicle stimulating hormone (FSH) is made by the pituitary gland in the brain. The calibration range of FSH is between $0.34-10 \mathrm{pg} / \mathrm{mL}$, and the limit of detection of FSH in the body is $10 \mathrm{pg} / \mathrm{mL}$. The tests used for determining the estrogen were the Elabscience Human/Monkey/Mouse Estrogen E-EL0150 Elisa kit, the progesterone was determined using the Elabscience Progesteron E-EL-1054, Elabscience Mouse FSH E-EL-M0511 and Elabscience Mouse LH E-EL-M3053 Elisa Kits.

\section{Data Analysis}

Single variance analysis (ANOVA) was used. Results are expressed as mean \pm SEM. F values for which $\mathrm{p}<$ 0.05 were considered statistically significant.

\section{Results and Discussion}

In this study we identified the differences between the multiparous and nulliparous groups according to the values of the four hormones: oestrogen, progesterone, LH and FSH, using experimental animals - Swiss mice, nulliparous and multiparous females. We analysed two groups of animals, one of 20 nulliparous female Swiss mice and 15 multiparous female Swiss mice.

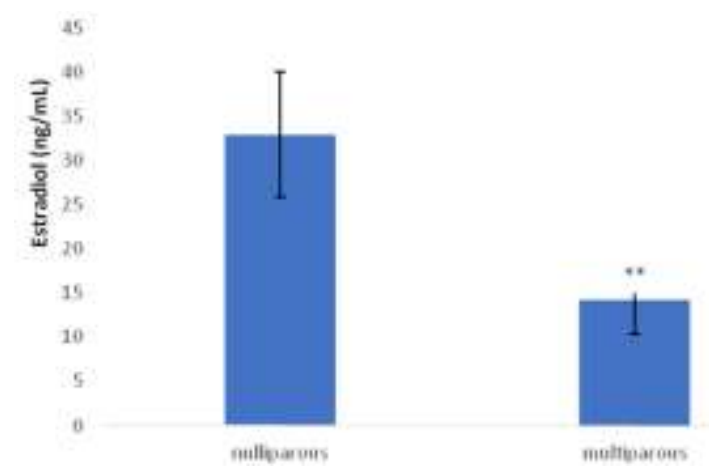

Figure 1.

Mean values in nulliparous and multiparous female mice for the levels of oestradiol

The values are presented as mean \pm S.E.M. $(n=20$ in nulliparous group and $\mathrm{n}=15$ in multiparous);

** $\mathrm{p}<0.001 \mathrm{vs}$. nulliparous group

Figure 1 is showing a difference between the averages values of the group of nulliparous female mice compared to the multiparous ones, in the oestrogen assessment. Thus, in the group of nulliparous female mice, an increase of the average values is observed, compared to the group of multiparous female mice.

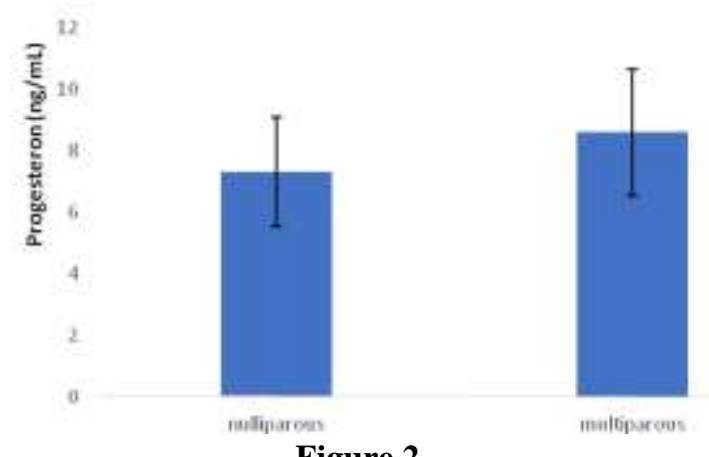

Figure 2.

Mean values in nulliparous and multiparous female mice for the levels of progesterone

The values are presented as mean \pm S.E.M. $(n=20$ in nulliparous group and $n=15$ in multiparous)

Figure 2 shows no significant differences between mean values for the group of nulliparous female mice, when compared to multiparous female mice in the analysis of progesterone. Thus, the differences between progesterone levels are not significant in the two groups of mice. 
Figure 3 represents a significant increase between mean values in the group of multiparous female mice compared to nulliparous ones, in the analysis of follicle-stimulating hormone. Thus, the FSH level is significantly increased in the group of multiparous female mice, compared to nulliparous ones.

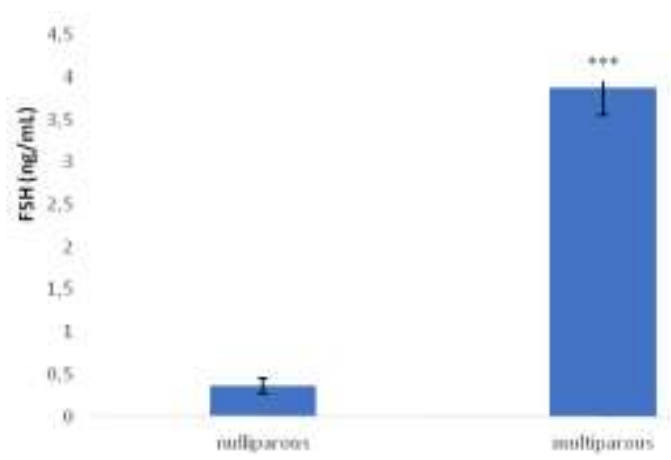

Figure 3.

Mean values in nulliparous and multiparous female mice for the FSH levels

The values are presented as mean \pm S.E.M. $(n=20$ in nulliparous group and $\mathrm{n}=15$ in multiparous); $* * * \mathrm{p}<0.0001 v s$. nulliparous group

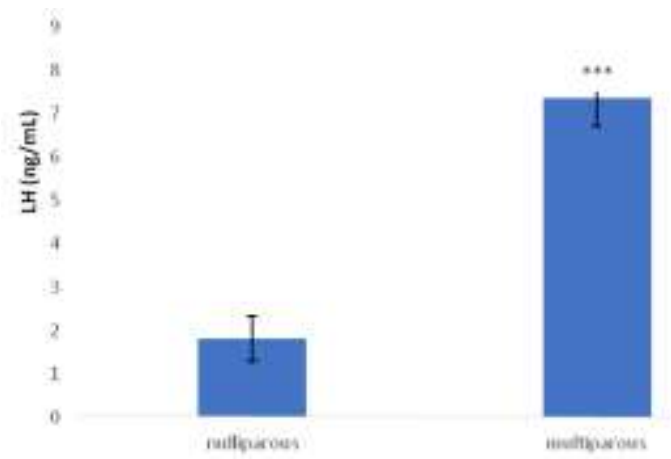

Figure 4.

Mean values in nulliparous and multiparous female mice for the levels of $\mathrm{LH}$

The values are presented as mean \pm S.E.M. $(n=20$ in nulliparous group and $\mathrm{n}=15$ in multiparous); $* * * \mathrm{p}<0.0001 v s$. nulliparous group

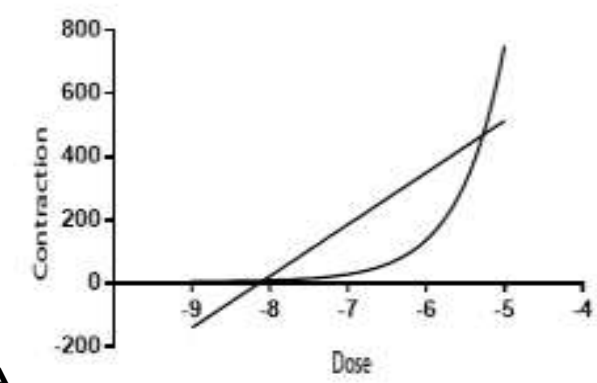

A

Dose

B

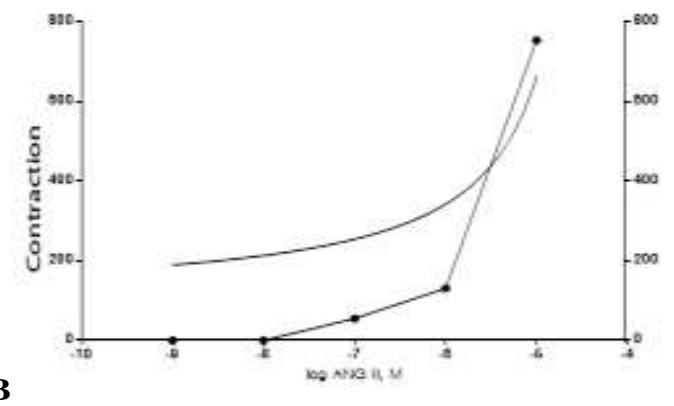

Figure 5.

A - Linear regression of the dose-effect curve to angiotensin; $\mathbf{B}$ - Dose-effect curve with nonlinear regression for comparison
Figure 4 represents a significant increase between the mean values in the group of multiparous female mice compared to nulliparous ones, in the luteinizing hormone analysis. Thus, the LH level is significantly increased in the group of multiparous female mice, compared to nulliparous ones.

Regarding the group differences between the nulliparous mice and multiparous mice, we observed that in multiparous female mice the values of FSH and LH have a significant increase compared to the nulliparous female, but at the same time, the analysis of progesterone did not show significant differences between the mean values of nulliparous female mice compared to multiparous female mice.

Our results are consistent with the observed relationship between menstrual cycles and the type of female mice used, nulliparous and multiparous. However, based on the analysis performed above, it was observed that the multiparous female does not undergo many changes during the menstrual cycle compared to the nulliparous female.

After analysing the four hormones, for each female mouse, we took the uterus, which was sectioned into $3-4 \mathrm{~mm}$ rings, and the uterine rings were mounted in $5 \mathrm{~mL}$ organ baths with Krebs-Henseleit serum bubbled with $\mathrm{O}_{2}-95 \%$ and $\mathrm{CO}_{2}-5 \%$ at $37^{\circ} \mathrm{C}$, then tested with angiotensin II $\left(10^{-5} \mathrm{M}\right)$. The preparations were equilibrated at a pressure of 1 gram for $60 \mathrm{~min}$. After balancing, the uterine rings were pre-contracted for reactivity testing. Stimulated electric field (SCE) was used to determine contractions. To record smooth muscle contractions, (isometric) force transducers coupled to a computerized acquisition system were used. The data acquisition was performed using an analogue-digital transducer and a set of horizontal transducers with $5 \mathrm{~mL}$ thermostatic bath, model Experimetria EXP-CLSG. All used substances were pure and purchased from specialized manufacturers. The uterine fragments were immediately placed in physiological saline (SSF) of the Krebs-Henseleit type, at $4^{\circ} \mathrm{C}$. These contractions allow the evaluation of the prepared reactivity, as well as the reproducibility of the results. 
Figure 5 shows the nonlinear regression used to evaluate the optimal dose interception point, giving us an EC50 of 4.246 and an optimal concentration/ contraction ratio obtained at a concentration of M5. Given that this concentration cannot be obtained

dose vs response
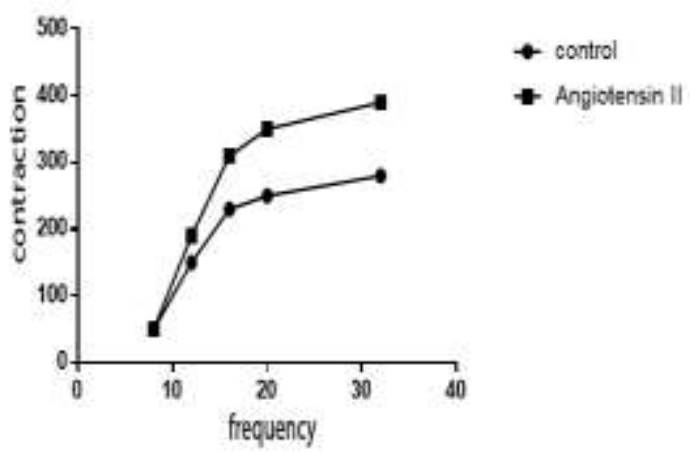

practically, for the subsequent investigations the concentration of $10^{-5} \mathrm{M}$ was used, which provided a maximum, reproducible and stable contraction for most of the preparations.

Figure 6.

Dose-effect comparison between control contraction and frequency-effect curve for angiotensin II

Figure 6 shows the dose-effect comparison between control contraction and angiotensin II frequency curve. Angiotensin II significantly increases muscle contractility stimulated by the electric field, as can be seen from the previous figure. So, the administration of angiotensin before electrical stimulation significantly increased the responsiveness to electrical stimulation.

These results show that the administration of angiotensin II in the nulliparous and multiparous female mice, in which hormonal assessment was performed, on uterine rings mounted in organ baths, significantly increases the muscle contractility stimulated by variations in the electrical field and by stimulating angiotensin receptors increases the amount of calcium available in smooth muscle cells, which amplifies the effect of electrical stimulation.

The present study investigated the relationship between sex steroid hormones, oestrogen and progesterone and pituitary hormones, such as luteinizing hormone and follicle stimulating hormone, during ovulatory menstrual cycle, by the influences of these hormones on the phases of the menstrual cycle in nulliparous and multiparous mice. Our results provide evidence of how the menstrual cycle is influenced by the physiological hormonal values. Studies on this topic show that ovarian steroid hormones have higher values among multiparous women compared to nulliparous ones, but nevertheless, further research is needed to elucidate any causal relationship [1]. But our results show that from the two ovarian hormones studied, only oestrogen has a significant increase in the group of nulliparous mice compared to the group of multiparous mice, while the progesterone values for the two studied groups show no significant changes. The two ovarian hormones, oestradiol and progesterone, are essential for a woman's reproduction, so oestradiol levels are correlated with growing dominant follicle size, oocyte quality, endometrial thickness and cervical mucus penetrability, and progesterone further helps prepare the endometrium for a potential pregnancy. Elevated concentrations of oestradiol and progesterone in a menstrual cycle are good indicators of fertility, the probability of conception being high [2,5].

We found that some studies suggest that oestradiol and progesterone levels in adulthood may be associated with sociodemographic factors, but surprisingly, very little is known about the extent to which oestradiol and progesterone vary with marital status and maternity in adult women $[1,3]$.

Most studies in women have failed to confirm a relationship between progesterone levels and performance on a variety of neuropsychological tests, although there is inconsistent evidence that progesterone may play a role in global-local processing, encoding emotional memory, or other processes of cognitive knowledge $[15,34]$. Several studies have stated that, among multiparous women, with a physiological menstrual cycle, they had on average higher concentrations of oestradiol than nulliparous women, but also higher concentrations of progesterone [17, 18]. We found only slight differences in the concentrations of oestradiol or progesterone compared to the state of motherhood. Some authors claim that in the nervous system, ovarian hormones have modulatory effects on neurotransmission and have an impact on the post-synaptic response, but also on the presynaptic release of neurotransmitters [19]. Certain functions of the serotonergic system are closely related to ovarian hormones and here we can integrate the premenstrual syndrome, which, more recently, is not related to the hormonal level, as it is considered, but to a special vulnerability of the central nervous system to physiological hormonal changes [32]. Some studies have shown that oestrogen inhibits the proliferation of smooth muscle cells in vascular walls, 
FARMACIA, 2021, Vol. 69, 1

which may also play a major role in preventing atherosclerosis [20]. Other scientific studies claim that oestrogens and progesterone directly influence brain function through oestrogen receptors located on neurons in several regions of the brain, through their neuroprotective and neurotrophic effects. At the same time, it stimulates the production of nerve growth factors, thus promoting neuronal growth and viability, the repair of damaged neurons and dendritic branches [7]. Also, quite recently, it has been found that progesterone or progestin could inhibit or accelerate neuroplasticity by preventing microglia from eliminating free radicals or by stimulating myelin production. There are many interactions with the dopaminergic and GABAergic systems, far too many to summarize, but it is certain that ovarian hormones have many excitatory, suppressive or inhibitory effects on neurotransmission, as well as progesterone which suppresses the excitatory response of glutamate, while oestrogen facilitates the glutamate transmission and induces the elimination of dopamine in the striatum. Another significant effect of oestrogen on brain tissue is the stimulation of cerebral vascularization, possibly by mechanisms similar to those that occur in the coronary arteries (by coupling with endothelial receptors and stimulating the release of nitric oxide, which causes vasodilation) [29]. Another action on cerebral vascularity is manifested by the anti-inflammatory effect of oestrogen in the vascular walls, protecting them from damage by cytokines and free radicals and preventing the formation of atherosclerotic plaques, resulting in the prevention of ischemic areas of brain tissue [23]. There is substantial evidence that ovarian sex hormones, oestrogen and progesterone, which vary considerably throughout a woman's life, contribute to changes in brain structure and function [24].

The secretion of FSH and $\mathrm{LH}$ is pulsating and is controlled by the intermittent release of gonadotropinreleasing hormone $(\mathrm{GnRH})$ from the hypothalamus, but at the same time regulates and stimulates gonadal growth and function [22]. The FSH-reducing allele was found to be associated with nulliparity, probably indicating increased female infertility. The relationship between FSH, LH and fertility during a woman's lifetime may differ from the age-related changes of FSH and LH around menopause. FSH is necessary for follicle development and it is proposed that an FSH threshold should be required to obtain ovulation. Ovulation increases with increasing FSH in transgenic mice with FSH levels that increase with age, regardless of follicle depletion. A high baseline level of FSH, determined by genetic variation, can promote ovulation and explain our association with parity [20].

Our study provides evidence that a probable functional variant in the FSH and $\mathrm{LH}$ promoter is strongly associated with longer menstrual cycles in multiparous compared to nulliparous women. Although we cannot rule out that the variant may have direct or indirect effects on other hormones levels, a change in oestrogen,
FSH and LH is most likely the primary mechanism. Thus, ovarian hormones, as well as pituitary hormones, through their effects, influence all the functional systems of the body: cardiovascular system, endocrine system, nervous system, digestive system, bone system, skin and blood [30]. These results are interesting in terms of the limited results of work on this topic and suggest several directions for future study.

As the present study is also part of a more comprehensive study, which took into account other hormones and biologically active substances, such as prostaglandins, angiotensin, oxytocin, vasopressin, we chose to insert in the context also angiotensin II, which is known to be a modulator of the myometrial activities, as both AT1 and AT2 receptors are expressed in the myometrium. Thus, its expression in the endometrium varies based also on the menstrual cycle, being at maximum in the proliferative phase, when it is located both in the glandular epithelium and in the stroma.

Angiotensin II may stimulate the expression of FSH receptor within the ovary, thus increasing the estrogen synthesis, but it did not modify progesterone secretion of aromatase activity. During the process of maturation, healthy and dominant follicles will not be subjected anymore to angiotensinergic influences [31]. In what concerns the LH, angiotensin seems to be involved in the paracrine regulation of the pituitary secretion, with stimulating effects [36].

Estrogens act on the RAS through various mechanisms, one of the most known ones being the inhibition of ACE enzyme, thus reducing circulating levels of ang II. This effect seems to be taking place at the level of the synthesis of ACE, by diminishing the synthesis of ACE mRNA [12]. Progesterone does not seem to have direct effect of the synthesis of the components of the RAS. However, the close similarity and the synthesis relationship between the molecules of progesterone and aldosterone might induce alterations in the plasma concentration of aldosterone, with effects on the hydric homeostasis [33].

In this way, some studies showed that oestrogen plays an important role in mediating the gestational increase in uterine artery blood flow, considering that the AT2 receptor-mediated responses are regulated in the presence of oestrogen and it increases substantially during pregnancy [7]. Also, given the findings that oestradiol also plays an important role in increasing uterine arterial blood flow [28], we suggest that oestradiol regulates AT2 receptors in uterine arteries.

In addition, in pregnant women, the plasma levels of angiotensin II appear to be five-fold higher than in non-pregnant controls, suggesting that Ang II receptors may be internalized [35]. Also, significant differences in AT1 and AT2 receptor expression levels and Ang II reactivity has been reported in the myometrium of pregnant women, when compared to those who are not pregnant [10]. 
FARMACIA, 2021, Vol. 69, 1

In fact, Ang II-induced contractile responses in intact uterine arteries of the endothelium in nulliparous mice were significantly decreased, when compared to multiparous mice [28]. Still, as the available data is still inconclusive, further evidence is clearly needed to verify the role of the local renin-angiotensin system in the physiological regulation of the endometrium and myometrium [7]. In this way, future studies should evaluate this local system in human uterine disorders. Also, a more complete knowledge of its role in the non-pregnant uterus is important and necessary, as it will diversify the possibilities in developing pharmacological approaches and new drugs for the treatment of significant gynaecological diseases [35].

\section{Conclusions}

We demonstrated a significant increase of the values for luteinizing and follicle-stimulant hormones and oestrogen in the two groups of mice, but no statistical significance for progesterone values. Thus, we have a significant increase between the values of the three hormones and the menstrual cycle phase for each female mouse, but no significance was found between the progesterone concentrations in the two groups and the phases of the menstrual cycle. The main effect was probably to change the sensitivity of the ovaries. In conclusion, we suggest that changes in oestrogen, FSH and LH levels lead to longer menstrual cycles with detrimental effects on female fertility.

\section{Conflict of interest}

The authors declare no conflict of interest.

\section{References}

1. Arslan AA, Zeleniuch-Jacquotte A, Lukanova A, Afanasyeva Y, Katz J, Levitz M, Del Priore G, Toniolo $\mathrm{P}$, Effects of parity on pregnancy hormonal profiles across ethnic groups with a diverse incidence of breast cancer. Cancer Epidemiol Biomarkers Prev., 2006; 15(11): 2123-2130.

2. Bergfeld EG, Kojima FN, Cupp AS, Wehrman ME, Peters KE, Mariscal V, Sanchez T, Kinder JE, Changing dose of progesterone results in sudden changes in frequency of luteinizing hormone pulses and secretion of 17 beta-estradiol in bovine females. Biol Reprod., 1996; 54(3): 546-553.

3. Bernstein L, Depue RH, Ross RK, Judd HL, Pike MC, Henderson BE, Higher maternal levels of free estradiol in first compared to second pregnancy: early gestational differences. J Natl Cancer Inst., 1986; 76(6): 1035-1039.

4. Bohiltea R, Furtunescu F, Turcan N, Navolan D, Ducu I, Cirstoiu M, Prematurity and Intrauterine Growth Restriction: Comparative Analysis of Incidence and Short-Term Complication. Proceedings of SOGR 2018. The 17 National Congress of the Romanian Society of Obstetrics and Gynecology, 2019; 708-712.
5. Byers SL, Wiles MV, Dunn SL,Taft RA, Mouse estrous cycle identification tool and images. PLoS One, 2012; 7(4): e35538: 1-5.

6. Caligioni CS, Assessing reproductive status/stages in mice. Curr Protoc Neurosci., 2009; Appendix 4: Appendix 4I: 1-11.

7. Casalechi M, Dela Cruz C, Lima LC, Maciel LP, Pereira VM, Reis FM, Angiotensin peptides in the non-gravid uterus: Paracrine actions beyond circulation. Peptides, 2018; 101: 145-149.

8. Catrinoiu D, Ceriello A, Rizzo M, Serafinceanu C, Montano N, Pantea Stoian A, Udeanu DI, Jinga V, Iorgulescu G, Dumitrescu IB, Diabetes and ReninAngiotensin-Aldosterone System: Implications for Covid-19 patients with diabetes treatment management. Farmacia, 2020; 68(3): 377-383.

9. Collins JS, Marshall JC, McCartney CR, Differential sleep-wake sensitivity of gonadotropin-releasing hormone secretion to progesterone inhibition in early pubertal girls. Neuroendocrinol., 2012; 96(3): 222-227.

10. Deliu E, Tica AA, Motoc D, Brailoiu GC, Brailoiu E, Intracellular angiotensin II activates rat myometrium. Am J Physiol Cell Physiol., 2011; 301(3): C559-565.

11. Exarcu IT, Pathophysiology of the ovary. In the physiology and pathophysiology of the endocrine system. Medicala Publishing House, Bucharest, 1989; 1046-1060, (available in Romanian).

12. Gallagher PE, Li P, Lenhart JR, Chappell MC, Brosnihan $\mathrm{KB}$, Estrogen Regulation of Angiotensin - Converting Enzyme mRNA. Hypertension, 1999; 33: 323-328.

13. Hasegawa A, Mochida K, Ogonuki N, Hirose M, Tomishima T, Inoue K, Ogura A, Efficient and scheduled production of pseudopregnant female mice for embryo transfer by estrous cycle synchronization. $J$ Reprod Dev., 2017; 63(6): 539-545.

14. Johnson ML, Pipes L, Veldhuis PP, Farhy LS, Boyd DG, Evans WS, AutoDecon, a deconvolution algorithm for identification and characterization of luteinizing hormone secretory bursts: description and validation using synthetic data. Anal Biochem., 2008; 381(1): 8-17.

15. Kerdelhue B, Brown S, Lenoir V, Queenan JTJr, Jones GS, Scholler R, Jones HWJr, Timing of initiation of the preovulatory luteinizing hormone surge and its relationship with the circadian cortisol rhythm in the human. Neuroendocrinology, 2002; 75(3): 158-163.

16. Krattenmacher R, Knauthe R, Parczyk K, Walker A, Hilgenfeldt U, Fritzemeier KH, Estrogen action on hepatic synthesis of angiotensinogen and IGF-I: direct and indirect estrogen effects. J Steroid Biochem Mol Biol., 1994; 48(2-3): 207-214.

17. Laboratory, Corporation of America. Directory of Services and Interpretive Guide. Progesterone, 2010, www.labcorp.com.

18. Liu JH, Yen SS, Induction of midcycle gonadotropin surge by ovarian steroids in women: a critical evaluation. J Clin Endocrinol Metab., 1983; 57(4): 797-802.

19. Loucks AB, Verdun M, Heath EM, Low energy availability, not stress of exercise, alters LH pulsatility in exercising women. J Appl Physiol., 1998; 84(1): 37-46.

20. MacLusky NJ, McEwen BS, Oestrogen modulates progestin receptor concentrations in some rat brain 
FARMACIA, 2021, Vol. 69, 1

regions but not in others. Nature, 1978; 274(5668): 276-278.

21. Maghiar F, Vicas LG, Ardelean A, Teusdea A, Tica OA, Oros C, Muresan, ME, Retrospective study on Angiotensin-Converting-Enzyme inhibitors treatment. Farmacia, 2020; 68(1): 90-96.

22. McCartney CR, Blank SK, Marshall JC, Progesterone acutely increases LH pulse amplitude but does not acutely influence nocturnal LH pulse frequency slowing during the late follicular phase in women. Am J Physiol Endocrinol Metab., 2007; 292(3): E900-906.

23. McCartney CR, Blank SK, Prendergast KA, Chhabra S, Eagleson CA, Helm KD, Yoo R, Chang RJ, Foster $\mathrm{CM}$, Caprio $\mathrm{S}$, Obesity and sex steroid changes across puberty: evidence for marked hyperandrogenemia in pre- and early pubertal obese girls. J Clin Endocrinol Metab., 2007; 92(2): 430-436.

24. McCartney CR, Prendergast KA, Blank SK, Helm KD, Chhabra S, Marshall JC, Maturation of luteinizing hormone (gonadotropin-releasing hormone) secretion across puberty: evidence for altered regulation in obese peripubertal girls. J Clin Endocrinol Metab., 2009; 94(1): 56-66.

25. Mervaala E, Muller DN, Schmidt F, Park JK, Gross V, Bader M, Breu V, Ganten D, Haller H, Luft FC, Blood pressure-independent effects in rats with human renin and angiotensinogen genes. Hypertension, 2000; 35(2): 587-594.

26. Miller BH, Takahashi JS, Central circadian control of female reproductive function. Front Endocrinol., 2013; 4: 195: 1-8.

27. Minakami H, Kimura K, Yano H, Kanazawa T, Tamada $\mathrm{T}$, The effects of progesterone on gonadotrophin release in hypogonadal women. Acta Endocrinol., 1984; 107(4): 456-461.

28. Mishra JS, Gopalakrishnan K, Kumar S, Pregnancy upregulates angiotensin type 2 receptor expression and increases blood flow in uterine arteries of rats. Biol Reprod., 2018; 99(5): 1091-1099.
29. Pastor CL, Griffin-Korf ML, Aloi JA, Evans WS, Marshall JC, Polycystic ovary syndrome: evidence for reduced sensitivity of the gonadotropin-releasing hormone pulse generator to inhibition by estradiol and progesterone. J Clin Endocrinol Metab., 1998; 83(2): 582-590.

30. Pielecka J, Quaynor SD, Moenter SM, Androgens increase gonadotropin-releasing hormone neuron firing activity in females and interfere with progesterone negative feedback. Endocrinology, 2006; 147(3): 1474-1479.

31. Pucell AG, Bumpus FM, Husain A. Regulation of angiotensin II receptors in cultured rat ovarian granulosa cells by follicle-stimulating hormone and angiotensin II. J Biol Chem., 1988; 263(24): 11954-11961.

32. Robinson JE, Forsdike RA, Taylor JA, In utero exposure of female lambs to testosterone reduces the sensitivity of the gonadotropin-releasing hormone neuronal network to inhibition by progesterone. Endocrinology, 1999; 140(12): 5797-5805.

33. Satué K, Domingo R, Redondo JI, Relationship between progesterone, oestrone sulphate and cortisol and the components of renin angiotensin aldosterone system in Spanish purebred broodmares during pregnancy, Theriogenology, 2011; 76(8): 1404-1415.

34. Staley K, Scharfman H, A woman's prerogative. Nat Neurosci., 2005; 8(6): 697-699.

35. Sullivan JA, Rupnow HL, Cale JM, Magness RR, Bird IM, Pregnancy and ovarian steroid regulation of angiotensin II type 1 and type 2 receptor expression in ovine uterine artery endothelium and vascular smooth muscle. Endothelium, 2005; 12(1-2): 41-56.

36. Yoldi A, Monreal M, Recio JM, Oleaga A, Salvador J, Moncada E, The renin-angiotensin system and anterior pituitary function: endocrine interaction or paracrine modulation?. Rev Med Univ Navarra, 1992; 37(4): 191-198. 